\title{
Genetic Variant of BDNF (Val66Met) Polymorphism Attenuates Stroke-Induced Angiogenic Responses by Enhancing Anti-Angiogenic Mediator CD36 Expression
}

\author{
Luye Qin, ${ }^{1}$ Eunhee Kim, ${ }^{1}$ Rajiv Ratan, ${ }^{1,2}$ Francis S. Lee, ${ }^{3}$ and Sunghee Cho ${ }^{1,2}$ \\ ${ }^{1}$ Burke-Cornell Medical Research Institute, White Plains, New York 10605, ${ }^{2}$ Department of Neurology and Neuroscience, Weill Medical College of Cornell \\ University, New York, New York 10016, and ${ }^{3}$ Departments of Psychiatry and Pharmacology, Weill Medical College of Cornell University, New York, New \\ York 10021
}

Brain-derived neurotrophic factor (BDNF) has been shown to be necessary and sufficient for post-stroke recovery in rodents. From these observations, we and others have hypothesized that a common single nucleotide polymorphism (SNP) in the pro-domain of $b d n f$ that leads to a methionine (Met) substitution for valine (Val) at codon 66 (Val66Met) will affect stroke outcome. Here we investigate the effect of the BDNF genetic variant on ischemic outcome by using mice with a genetic knock-in of the human BDNF variant in both alleles $\left(B D N F^{M e t / M e t}\right)$. Compared with wild-type mice, $B D N F^{M e t / M e t}$ mice exhibited reduced CNS BDNF levels without a discernable effect on infarct size. Diminished BDNF levels in $B D N F^{M e t / M e t}$ mice were associated with greater deficits in post-stroke locomotor functions. Additionally, the $B D N F^{M e t / M e t}$ mice showed reduced angiogenesis and elevated expression of thrombospondin-1 (TSP-1) and its receptor CD36, anti-angiogenic factors. To assess the functional role of CD36 in antagonizing angiogenic response in Met homozygosity at the BDNF locus, we crossed $B D N F^{M e t / M e t}$ mice with $\mathrm{CD} 36$ knock-out mice. The double-mutant mice rescued the angiogenic deficit associated with the $B D N F^{M e t / M e t}$ mice without alterations in BDNF levels, indicating that the behavioral deficit in $B D N F^{M e t / M e t}$ mice after stroke is partly related to an unfavorable balance in pro-angiogenic BDNF and anti-angiogenic TSP-1/CD36. The results suggest that CD36 inhibition may be a viable strategy to enhance angiogenesis and possible recovery in human stroke victims who are Met homozygotes at codon 66 of the BDNF locus.

\section{Introduction}

Unlike vasculogenesis, neoangiogenesis after stroke involves sprouting of new vessels from preexisting vessels (Hayashi et al., 2006). Enhanced angiogenesis in the ischemic penumbra is correlated with increased survival of stroke patients (Krupinski et al., 1994). Furthermore, the promotion of ischemia-induced angiogenesis within the ischemic boundary was suggested as a therapeutic strategy to improve stroke outcome (Rosell-Novel et al., 2004; Slevin et al., 2006).

Brain-derived neurotrophic factor (BDNF) promotes neuronal survival, differentiation, synaptic plasticity, and angiogenesis in normal and ischemic tissue (Donovan et al., 2000; Chao, 2003; Kermani et al., 2005; Wagner et al., 2005; Tongiorgi, 2008). BDNF expression is upregulated in the boundary of the infarct with much less expression in the infarct core (Kokaia et al., 1995, 1998). Whereas most studies indicate that enhanced BDNF availability and signaling ameliorate ischemic brain damage and func-

\footnotetext{
Received Aug. 31, 2010; revised 0ct. 25, 2010; accepted 0ct. 30, 2010.

This work was supported by National Institutes of Health Grants HL82511 (S.C.), MH088814 (F.S.L., S.C.), and NS052819 (F.S.L.) and the Burke Foundation.

Correspondence should be addressed to Dr. Sunghee Cho, Department of Neuroscience, Weill Cornell Medical College at Burke Medical Research Institute, 785 Mamaroneck Avenue, White Plains, NY 10605. E-mail: suc2002@med.cornell.edu.

DOI:10.1523/JNEUROSCI.4547-10.2011

Copyright $\odot 2011$ the authors $\quad 0270-6474 / 11 / 310775-09 \$ 15.00 / 0$
}

tional recovery, some argue against the beneficial effect of BDNF (Gustafsson et al., 2003; Nygren et al., 2006).

A single nucleotide polymorphism (SNP) of the bdnf gene, which results in the substitution of a valine (Val) to a methionine (Met) in the prodomain of the BDNF protein, was identified. This exclusively human SNP occurs with relatively high frequency (Ventriglia et al., 2002; Egan et al., 2003; Itoh et al., 2004; He et al., 2007). Identified as the first genetic alteration in the neurotrophin system, the BDNF has been implicated in conferring susceptibility to various neuropsychiatric disorders and altered episodic memory in patients with psychiatric disease (Sklar et al., 2002; Egan et al., 2003; Sen et al., 2003). Although studies on the impact of the BDNF polymorphism in the outcome after ischemic stroke are limited, clinical studies suggest a correlation of this BDNF polymorphism with poor outcome in hemorrhagic stroke patients (Siironen et al., 2007; Vilkki et al., 2008).

Angiogenesis is tightly regulated by factors that promote as well as inhibit vessel formation. Whereas BDNF evokes proangiogenic responses in the ischemic hindlimb (Kermani et al., 2005; Kermani and Hempstead, 2007), ischemia also upregulates the angiostatic receptor CD36 in the post-ischemic brain (Cho et al., 2005). CD36 is expressed in the microvascular endothelium, and the interaction of CD36 with thrombospondin (TSP)-1 and TSP-2 mediates a signaling cascade that leads to endothelial cell apoptosis (Jiménez et al., 2000; Febbraio et al., 2001), offsetting compensatory angiogenesis-promoting cascades. Although CD36 
expression is relatively low in the normal brain, increased expression of CD36 and TSPs has been reported after cerebral ischemia (Hayashi et al., 2003; Lin et al., 2003; Cho et al., 2005). The current study investigates the impact of BDNF SNP on ischemic outcome and angiogenic response using mice with a genetic knock-in of the human $b d n f$ Val66Met variant. This study clarifies potential interactions between angiogenic and angiostatic factors to regulate angiogenesis in the post-ischemic brain. We report that the BDNF SNP contributed to reductions in strokeinduced BDNF release, poorer behavioral outcome, and deficits in angiogenic response. We also determined that the absence of CD36 can rescue the angiogenesis deficit in mice with the BDNF SNP.

\section{Materials and Methods}

Animals. The use of animals and procedures performed were approved by the Institutional Animal Care and Use Committee of Weill Medical College of Cornell University. Experiments were performed in $B D N F^{+/+}$ wild-type and $B D N F^{M e t / M e t}$ mutant mice generated and housed at Weill Cornell Medical College. These mice were backcrossed 10 times into the $\mathrm{C} 57 \mathrm{BL} / 6$ strain, and the procedures for heterozygote breeding and genotyping were described previously (Chen et al., 2006). CD36 knock-out (KO) mice were generated by Dr. Maria Febbraio at Weill Cornell Medical College and backcrossed seven times into the C57BL/6 strain. The procedures for breeding and genotyping were described previously (Febbraio et al., 1999, 2000). BDNF $F^{\text {Met/Met }} / C D 36^{-/-}$double mutants (Dmt) $(8 \times$ backcrossed $\mathrm{C} 57 \mathrm{BL} / 6)$ and background matching $B D N F^{\text {Met/Met }} /$ $\mathrm{CD} 6^{+/+}$controls (Dwt) were generated by crossing $B D N F^{\text {Met/Met }}$ mice with CD36 KO mice. All mouse lines were housed at the Burke Medical Research Institute.

Transient middle cerebral artery occlusion. Procedures for middle cerebral artery occlusion (MCAO) were described previously (Cho et al., 2005, 2007). Both male and female mice were used to determine infarct volume and percentage hemispheric swelling. For the rest of the study, only male mice were used. Briefly, mice were anesthetized with a mixture of isoflurane/oxygen/nitrogen. A fiber optic probe was glued to the right parietal bone ( $2 \mathrm{~mm}$ posterior and $5 \mathrm{~mm}$ lateral to bregma) and connected to a laser-Doppler flowmeter (Periflux System 5010; Perimed) for continuous monitoring of cerebral blood flow $(\mathrm{CBF})$ in the center of the ischemic territory. For MCAO, a 6-0 Teflon-coated black monofilament surgical suture (Doccol Co.) was inserted into the exposed external carotid artery, advanced into the internal carotid artery, and wedged into the cerebral arterial circle to obstruct the origin of the MCA. The filament was left in place for $30 \mathrm{~min}$ and then withdrawn. Only animals that exhibited both a reduction in $\mathrm{CBF}>80 \%$ during $\mathrm{MCAO}$ and a recovery of $\mathrm{CBF}>80 \%$ by $10 \mathrm{~min}$ after reperfusion were included in the study. This procedure leads to similar blood flow reduction and reperfusion among the groups and to reproducible infarcts involving both the cerebral cortex and the striatum in the right hemisphere (Cho et al., 2005).

Behavior testing. Functional outcome was assessed using a rotarod (Med Associates) and a Noldus Catwalk XT gait analysis system (Noldus Information Technology). These rotarod and Catwalk systems were used to assess functional recovery after stroke and other CNS injury (Hamers et al., 2006; Liauw et al., 2008; Wang et al., 2008; Neumann et al., 2009). For the rotarod test, the device was set to accelerate from 4 to $40 \mathrm{rpm}$ over the course of $5 \mathrm{~min}$. The animals were pretrained 6 consecutive days before ischemia, and post-stroke testing was performed $6 \mathrm{~d}$ after MCAO. The latency to fall from the rod (performance) was recorded and averaged for five trials. For the Catwalk gait analysis system, mice were pretrained daily for 2 weeks to cross an illuminated glass walkway three consecutive times and then tested at $1 \mathrm{~d}, 4 \mathrm{~d}, 7 \mathrm{~d}, 2$ weeks, and 1 month after MCAO. The images from each trial that consist of three consecutive runs were converted into digital signals. After classification of each footprint, spatial parameters based on individual paws (maximum contact area and mean intensity), relative positions between paws [stride length and base of support (BOS)], temporal parameters (stand and swing speed), and parameter related to interlimb coordination (regularity index) were determined.
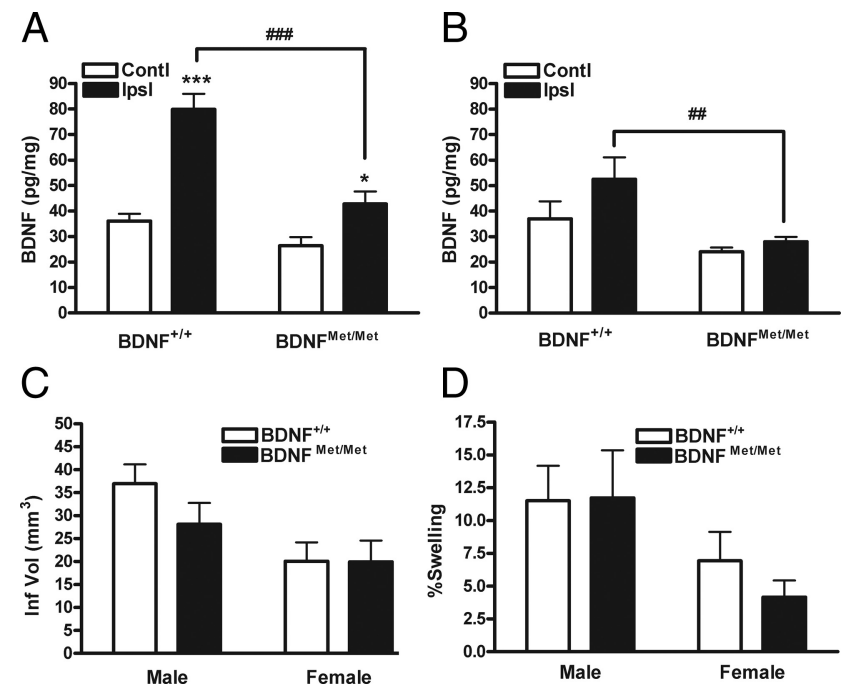

Figure 1. Effect of BDNF Val66Met polymorphism on BDNF levels and ischemic outcome. Total BDNF levels from brain lysates were determined in $B D N F^{+/+}$and $B D N F^{M e t / M e t}$ mice using BDNF ELISA at $3 \mathrm{~d}(\boldsymbol{A})$ and $7 \mathrm{~d}(\boldsymbol{B})$ after stroke. Note that BDNF SNP resulted in a significant reduction of stroke-induced BDNF secretion. $n=5-10$ per group. ${ }^{*} p<0.05$ and ${ }^{* * *} p<0.001$ versus contralateral; ${ }^{\# \#} p<0.01$ and ${ }^{\# \# \#} p<0.001$ versus $B D N F^{+/+}$ipsilateral. Contl, Contralateral; Ipsl, ipsilateral. Infarct volume ( Inf Vol) $(\boldsymbol{C})$ and percentage hemispheric swelling $(\boldsymbol{D})$ were determined $3 \mathrm{~d}$ after ischemia in male and female $B D N F^{+/+}$and $B D N F^{M e t / M e t}$ mice. No difference in ischemic outcomes was found between the genotypes. $n=11-15$ per group.

Tissue preparation. Mice were killed 3 or $7 \mathrm{~d}$ after MCAO. Brains were excised, frozen, and sectioned using a cryostat. Because infarct typically spans $\sim 6 \mathrm{~mm}$ rostrocaudally starting from $+2.8 \mathrm{~mm}$ from bregma and extending to $-3.8 \mathrm{~mm}$, we used an unbiased stereological sampling strategy to collect tissue in this region that included infarct. Tissue sections were collected serially for measurement of infarct volume/immunohistochemistry (20 $\mu \mathrm{m}$ thickness) and for gene expression and ELISA (100 $\mu \mathrm{m})$ at a $600 \mu \mathrm{m}$ intervals.

Measurement of infarct volume and swellings. Infarct volume and percentage hemispheric swelling were determined in serial sections using Axiovision software (Carl Zeiss). The contribution resulting from swelling was corrected using a method described previously (Lin et al., 1993).

BDNF ELISA. The BDNF protein concentrations were determined in the brain lysates using the BDNF Emax immunoassay system, recombinant mature BDNF as a standard according to the instructions of the manufacturer (Promega).

Immunohistochemistry. Brain sections were completely air dried and subsequently fixed in $-20^{\circ} \mathrm{C}$ methanol for $2-3 \mathrm{~min}$ or $4 \%$ paraformaldehyde for $15 \mathrm{~min}$, then washed three times in PBS at pH 7.4, and incubated in $0.2 \%$ Triton X-100 for 5 min. After washing with PBS, slides were blocked in $1 \%$ BSA (Sigma) in PBS containing 5\% normal goat serum for $1 \mathrm{~h}$ at room temperature, followed by overnight incubation with primary antibodies: Ki-67 (cell proliferation marker, 1:000; Abcam), CD31 (endothelial marker, 1:1000; Millipore Bioscience Research Reagents), CD36 (1:300; Santa Cruz Biotechnology), and glial fibrillary acidic protein (GFAP) (astrocytes marker, 1:3000; Millipore Bioscience Research Reagents). Sections were washed with PBS, incubated with secondary antibodies conjugated with Alexa Fluor 488 or 594 (1:200; Invitrogen) for $1 \mathrm{~h}$ at room temperature, and coverslipped to examine under a florescent microscope or laser scanning confocal microscopy (Carl Zeiss).

Assessment of proliferating endothelial cells. Double-fluorescence immunohistochemistry of Ki-67 and CD31 was performed $3 \mathrm{~d}$ after ischemia. Using a laser scanning confocal microscope, the number of proliferating endothelial cells was identified by nuclear staining of Ki-67 juxtaposed CD31-immunoreactive endothelial cells in the entire infarct area. The density of proliferating endothelial cells was obtained from the total number of $\mathrm{Ki}-67 / \mathrm{CD} 31$-positive $\left(\mathrm{CD} 31^{+}\right)$cells divided by the entire infarct area. A section at the level of striatum $(+1.2$ from bregma) 
Table 1. Body weight, CBF reduction and reperfusion, and breakdown of the numbers of mice that were included in the study

\begin{tabular}{|c|c|c|c|c|}
\hline & Male/BDNF ${ }^{+/+}$ & Male/BDNF $F^{M e t / M e t}$ & Female/BDNF ${ }^{+/+}$ & Female/BDNF $^{\text {Met/Met }}$ \\
\hline Total number of animals & 30 & 30 & 14 & 11 \\
\hline Body weight (g) & $25.6 \pm 0.26$ & $25.8 \pm 0.42$ & $21.2 \pm 0.32$ & $24.2 \pm 0.8^{* * *}$ \\
\hline CBF reduction (\%) & $89.38 \pm 0.66$ & $87.53 \pm 1.0$ & $88.3 \pm 1.0$ & $85.4 \pm 1.2$ \\
\hline CBF reperfusion (\%) & $114.6 \pm 3.98$ & $111.7 \pm 7.43$ & $110.9 \pm 6.1$ & $107.8 \pm 3.9$ \\
\hline Failed MCAO & 3 & 5 & 1 & None \\
\hline Mortality & 6 & 6 & 1 & None \\
\hline Animals entered the study & 21 & 19 & 12 & 11 \\
\hline
\end{tabular}

Body weight and CBF values are expressed as mean \pm SEM. ${ }^{* * *} p<0.001$ versus Female $/ B D N F^{+/+}$

A

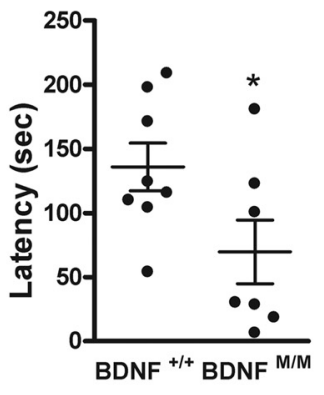

C

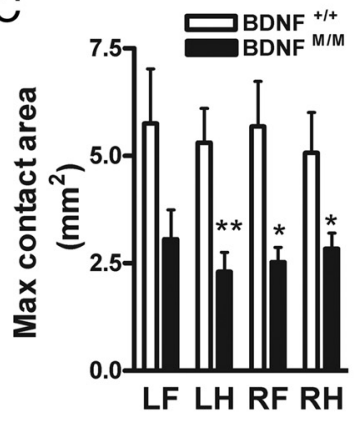

D

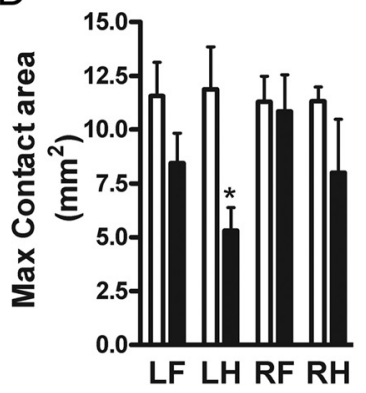

B
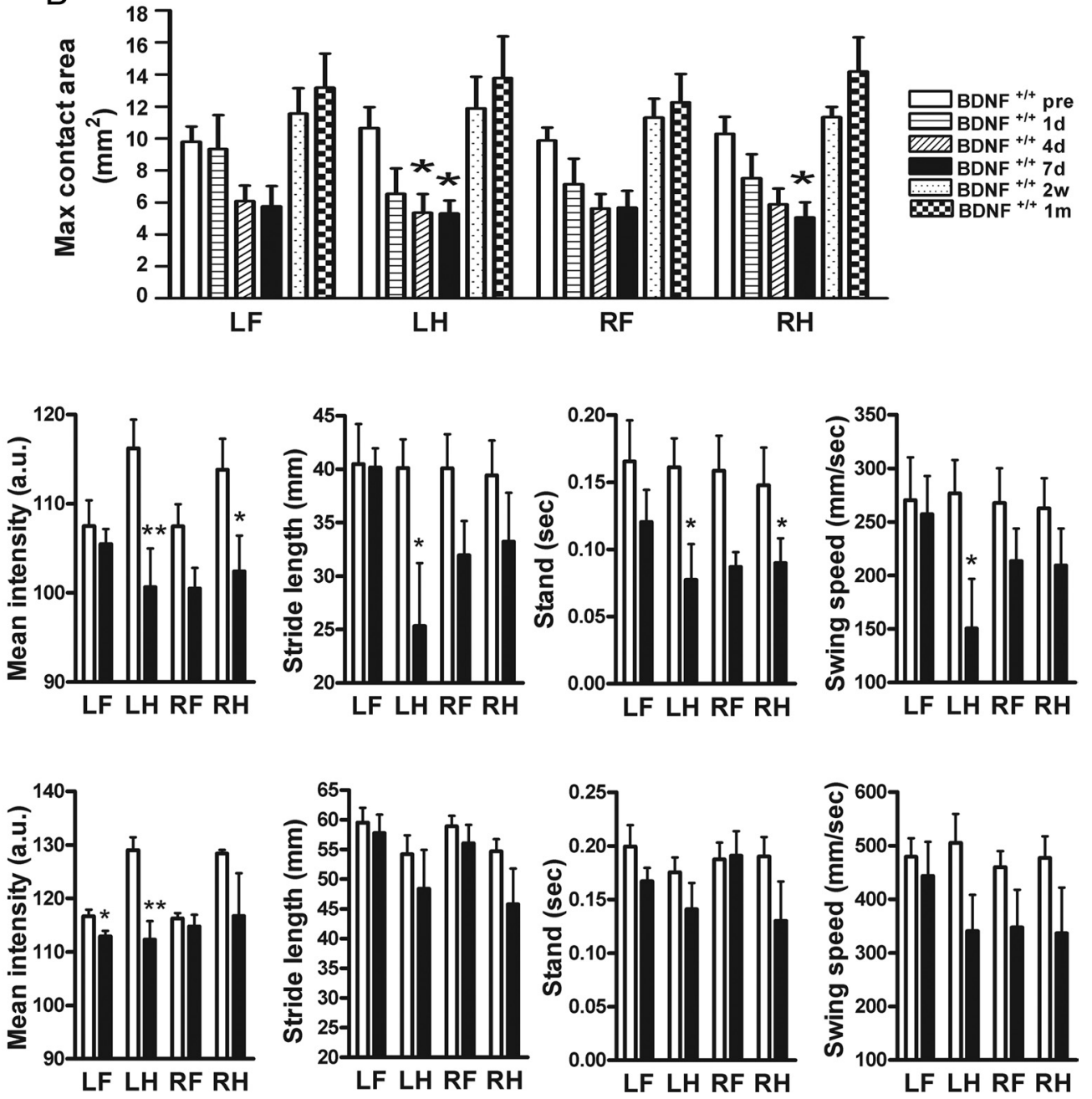

Figure 2. Effect of BDNF Val66Met polymorphism on motor behavior after stroke. Behavioral testing in $B D N F^{+/+}$and $B D N F^{\text {Met/Met }}$ mice. All animals were trained for each testing before stroke. $A$, Mice were subjected to a rotarod, and latencies to fall were compared $6 \mathrm{~d}$ after ischemia. $n=7-8$ per group. $\boldsymbol{B}$, Gait changes were assessed by a computer-assisted Catwalk gait analysis system. Temporal changes of maximum contact area $(B)$ in $B D N F^{+/+}$mice before ischemia (pre) and $1 \mathrm{~d}, 4 \mathrm{~d}, 7 \mathrm{~d}, 2$ weeks, and 1 month after ischemia. $C$, Comparison between $B D N F^{+/+}$and $B D N F^{\text {Met/Met }}$ micee in stroke-induced gait changes at $7 \mathrm{~d}$ after ischemia. Max contact area, The maximum area of a paw that comes into contact with the glass plate; Mean intensity, a measure of pressure (a.u., arbitrary unit) exerted on the glass plate; Stride length, the distance between consecutive steps with the same paw; Stand, a duration in seconds of contact of a paw with the glass plate; Swing speed, the speed (millimeters per seconds) of the paw during swing. $\boldsymbol{D}$, Comparison between $B D N F^{+/+}$and $B D N F^{\text {Met/Met }}$ mice in stroke-induced gait changes at 2 weeks after ischemia. $n=6-10$ per group. ${ }^{*} p<0.05$ versus $B D N F^{+/+}$mice before ischemia in $\boldsymbol{B}$. ${ }^{*} p<0.05$ and ${ }^{* *} p<0.01$ versus $B D N F^{+/+}$mice in $C$ and $D$. LF, Left forepaw; $L H$, left hindpaw; $R F$, right forepaw; $R H$, right hindpaw.

was stained, counted, and averaged to represent the density for an animal. Values were presented as cell number per square millimeter.

Assessment of vessel density. Double-fluorescence immunohistochemistry of GFAP and CD31 was performed $7 \mathrm{~d}$ after ischemia. To quantify vessel density, we modified our published nonbiased counting method (Cho et al., 1997). A $10 \times 10$ grid in a $0.1 \mathrm{~mm}^{2}$ frame was placed along the glial scar that is demarcated by GFAP immunoreactivity as shown in Figure $4 G$. For each animal, CD31 ${ }^{+}$vessels that cross grid lines were counted in a section $(+1.2 \mathrm{~mm}$ from bregma). The number of intersec- tions within a frame was counted and averaged from 7-10 randomly chosen inner and outer fields along the glial scar. The total number of intersections from the field was averaged to represent an inner and outer vessel density for each animal. Values were presented as number of intersections per frame area $\left(0.1 \mathrm{~mm}^{2}\right)$.

Real-time reverse transcription-PCR for CD36, CD47, and TSP-1/2 gene expression. Relative mRNA levels of CD36, CD47, and TSP-1/2 were quantified with real-time quantitative reverse transcription-PCR using fluorescent TaqMan technology (Cho et al., 2007; Kim et al., 2008). Total RNA 
was extracted from brain tissues using TRI Reagent (Molecular Research Center). Total RNA from brain tissues was reverse transcribed using oligo-dT primers and the SuperScript FirstStrand Synthesis System (Invitrogen), according to the protocol of the manufacturer. PCR primers and probes specific for CD47, CD36, and TSP$1 / 2$ and $\beta$-actin were obtained as TaqMan predeveloped assay reagents for gene expression (Applied Biosystems). $\beta$-Actin was used as an internal control for normalization of samples. The PCR reaction was performed using FastStart Universal Probe Master (Roche) and Applied Biosystems 7500 Fast Real-Time PCR system, according to the instructions of the manufacturer. Reactions were performed in $20 \mu \mathrm{l}$ total volume and incubated at $95^{\circ} \mathrm{C}$ for $10 \mathrm{~min}$, followed by $40 \mathrm{cy}$ cles of $15 \mathrm{~s}$ at $95^{\circ} \mathrm{C}$ and $1 \mathrm{~min}$ at $60^{\circ} \mathrm{C}$. The results were analyzed by 7500 Fast Real-Time PCR System software.

Statistics. Data are presented as mean \pm SEM. All analyses were performed, and analyzed data were graphed using GraphPad Software Prism 4.0. Comparisons between two groups were statistically evaluated by the Student's $t$ test. Multiple comparisons were made using two-way ANOVA. Differences were considered significant at $p<0.05$.

\section{Results}

\section{Mice with the BDNF SNP exhibit} reduced stroke-induced BDNF levels without affecting injury size

To investigate the effect of the BDNF Val66Met SNP on ischemic outcome, we first determined whether the BDNF SNP has an effect on stroke-induced BDNF levels in the brain. Because ischemia upregulates BDNF transcript and protein expression (Kokaia et al., 1995; Krikov et al., 2008), we initially determined temporal changes in strokeinduced BDNF level using an entire hemisphere of $\mathrm{C} 57 \mathrm{BL} / 6$ mice. Stroke-induced BDNF levels were increased at 3-7 d (supplemental Fig. S1, available at www.jneurosci.org as supplemental material). Using these time points, tissue was serially sectioned through the infarct territory (see Materials and Methods), and stroke-induced BDNF levels were compared. $B D N F^{M e t / M e t}$ mice exhibited lower BDNF levels relative to wild type at 3 and $7 \mathrm{~d}$ after ischemia, with a larger difference at $3 \mathrm{~d}$ (Fig. $1 A, B$ ). Infarct size and hemispheric swelling, assessed at $3 \mathrm{~d}$ after ischemia between two genotypes, were not different in both genders (Fig. $1 C, D$ ). No differences in cerebral blood flow reduction and reperfusion during and $10 \mathrm{~min}$ after ischemia suggests that the severity of ischemia was comparable between $B D N F^{+/+}$and $B D N F^{\text {Met/Met }}$ mice (Table 1). The dissociation between BDNF levels and ischemic outcomes indicates that the amount of BDNF in the post-ischemic brain is not a critical factor for acute infarct development.

\section{Mice with the BDNF SNP exhibit poorer motor behavioral outcomes after stroke}

Post-ischemic motor function was assessed in $B D N F^{+/+}$and $B D N F^{M e t / M e t}$ mice. There was no difference between the genotypes in rotarod performance before ischemia. Compared with $B D N F^{+/+}$mice, $B D N F^{M e t / M e t}$ mice showed a significantly larger deficit $6 \mathrm{~d}$ after stroke (Fig. $2 \mathrm{~A}$ ). Temporal profiles of gait analysis in $B D N F^{+/+}$mice revealed that maximum contact area, a spatial
$\mathrm{BDNF}^{+/+}$
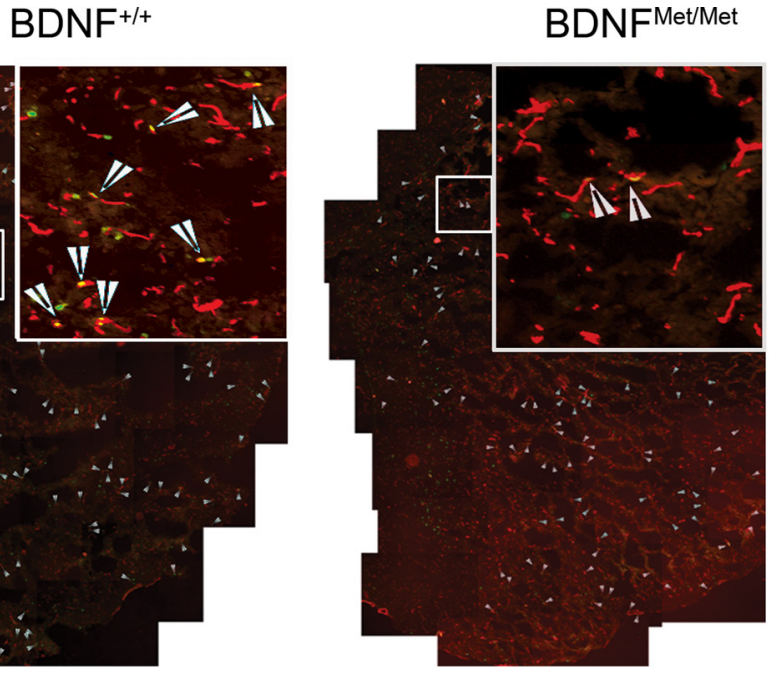

C
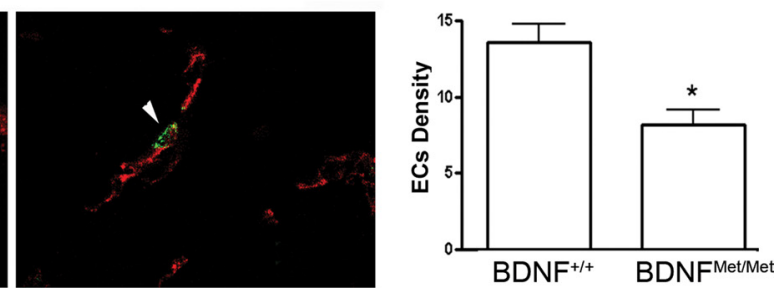

$\mathrm{BDNF}^{+/+} \quad \mathrm{BDNF}^{\mathrm{Met} / \mathrm{Met}}$

Figure 3. Effect of BDNF Val66Met polymorphism on the proliferation of endothelial cells in the infarct territory. Proliferating endothelial cells were identified at $3 \mathrm{~d}$ after ischemia by double immunohistochemistry of Ki-67/CD31 in the infarct area. $A, A$ 作 is a significant reduction in proliferating endothelial cells (EC) in BDNF ${ }^{M e t / M e t}$ mice. Error bars indicate mean \pm SEM; $n=3$ per group. ${ }^{*} p<0.05$ compared with $B D N F^{+/+}$mice.

parameter related to individual paws, showed a progressive decrease, with the greatest deficits at $7 \mathrm{~d}$ after ischemia in all four paws, and returned to baseline levels at 2 weeks and 1 month after ischemia (Fig. $2 \mathrm{~B}$ ). Other spatial and temporal parameters, including mean intensity, stride length, stand, swing speed, and regularity index, show a similar temporal pattern except BOS, which increases over 1 month after ischemia (supplemental Fig. S2, available at www.jneurosci.org as supplemental material). The gait function between the genotypes was compared at $7 \mathrm{~d}, 2$ weeks, and 1 month after ischemia. Compared with $B D N F^{+/+}$ mice, $B D N F^{\text {Met/Met }}$ mice showed greater deficits in maximum contact area in all paws at $7 \mathrm{~d}$ after ischemia. Reduced pressure exerted on the glass plate (mean intensity) in left and right hindpaws, shorter stride length in left hindpaws, shorter duration for the paw to contact the plate (stand) in left hindpaws and right forepaws, and the slower speed of the paw during swing (swing speed) in left hindpaws were found (Fig. 2C). Importantly, several $B D N F^{M e t / M e t}$ mice exhibited paw pressure below detection limit during the acute phase $(<7 \mathrm{~d})$, whereas all of $B D N F^{+/+}$ mice were in detection range, indicating that $B D N F^{\text {Met/Met }}$ mice exhibited a greater deficit. Within $B D N F^{M e t / M e t}$ mice, we were unable to detect paw pressure in three of nine for forepaws and one of nine for hindpaws at the contralateral side at $7 \mathrm{~d}$. This indicates greater deficits in the forepaw than hindpaw at this time. For data presentation, instead of arbitrarily assigning zero for these undetected animals, we performed statistical analysis only in animals 

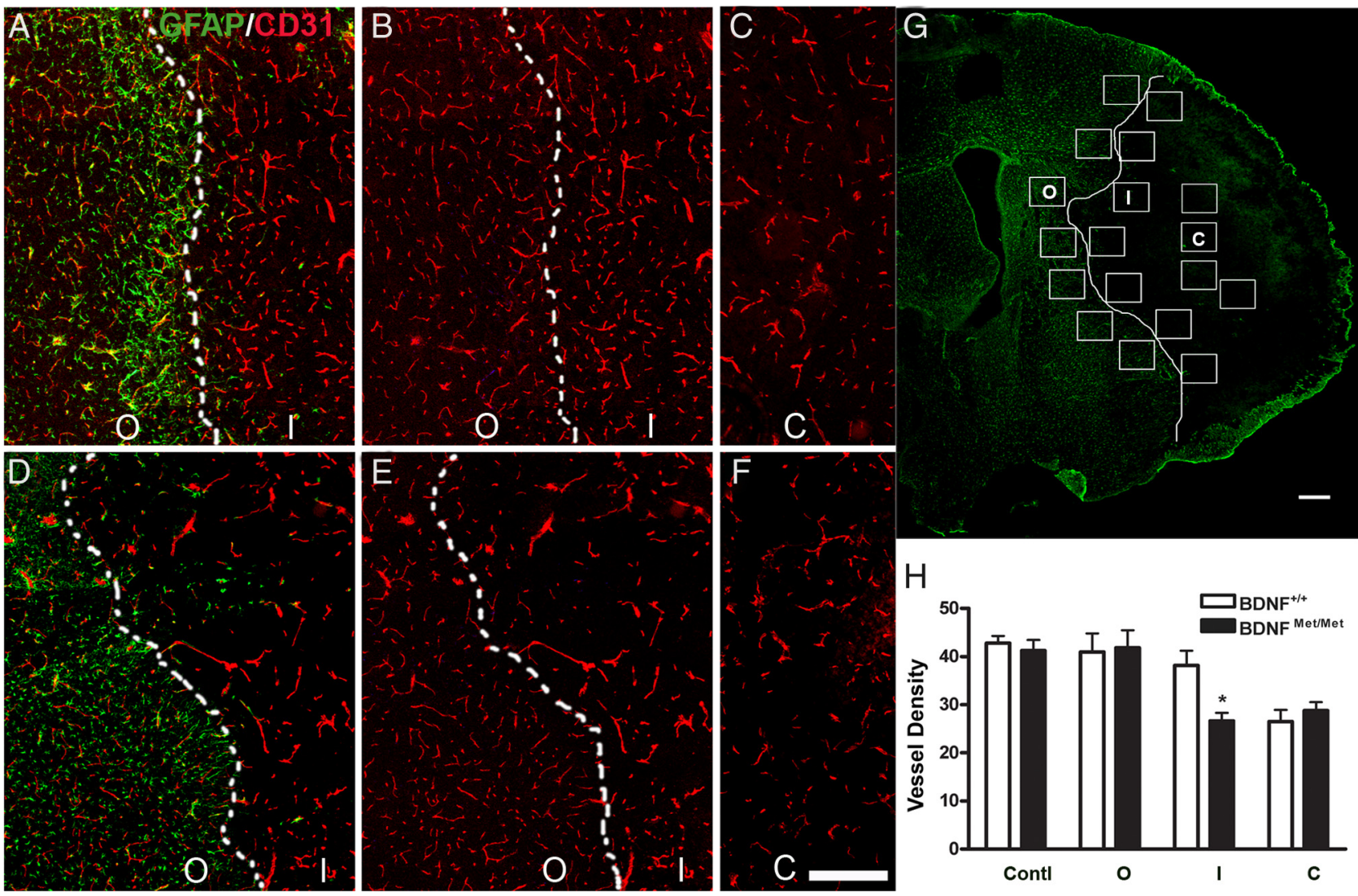

Figure 4. Effect of BDNF Val66Met polymorphism on vessel density in the peri-infarct area. Vessel density was determined in the outer and inner margin of infarct border defined by glial scar $7 \mathrm{~d}$ after ischemia. $\boldsymbol{A}-\mathbf{G}$, Immunohistochemistry of GFAP (green) and/or CD31 (red) in $B D N F^{+/+}(\boldsymbol{A}-\boldsymbol{C})$ and BDNFMet/Met $(\boldsymbol{D}-\boldsymbol{F})$ mice. Note that there is strong GFAP immunoreactivity in the outer margin of infarct border indicated by dotted white lines $(\boldsymbol{A}, \boldsymbol{D})$. The inner margin of infarct border is indicated by dotted or solid white lines. $G$, Seven to 10 fields (shown as squares, area for each square is $0.1 \mathrm{~mm}^{2}$ ) from each section are chosen along the white infarct border. $\boldsymbol{H}$, Quantification of vessel density in the core (C) and inner (I) and outer (0) margin of infarct border, and contralateral side (Contl) was compared between $B D N F^{+/+}$and BDNF ${ }^{M e t / M e t}$ mice. $n=4-5$ per group. ${ }^{*} p<0.05$ versus $B D N F^{+/+}$mice inner margin. Scale bar, $300 \mu \mathrm{m}$.

that registered enough paw pressure. Thus, this quantitative comparison underestimates the deficit of forepaw. No difference was found in BOS (a parameter for the relative positions between paws) $\left(B D N F^{+/+}\right.$vs $B D N F^{M e t / M e t}$ : forepaws, $5.8 \pm 2.1 \mathrm{vs} 7.2 \pm 1.4 \mathrm{~mm}$; hindpaws, $12.7 \pm 4.2$ vs $14.2 \pm 2.7 \mathrm{~mm}$; NS). Although $B D N F^{\text {Met/Met }}$ mice showed a reduced regularity index (a parameter for degree of interlimb coordination), it did not reach statistical significance $\left(B D N F^{+/+}\right.$vs BDNF ${ }^{M e t / M e t}: 67.2 \pm 7.2$ vs $\left.40.6 \pm 10.9 \% ; p=0.0515\right)$. All these deficits in the paws contralateral to the stroked side in $B D N F^{M e t / M e t}$ mice are indicative of unstable and impaired gait in the acute stage. Although $\mathrm{BDNF}^{+/+}$mice returned to baseline at 2 weeks after ischemia, $B D N F^{\text {Met/Met }}$ mice showed deficits in maximum contact area in left hindpaw and mean intensity in left forepaw and left hindpaw (Fig. 2D). There were no behavior differences at 1 month after ischemia. These behavior results showed that $B D N F^{\text {Met/Met }}$ mice exhibited greater deficits in locomotor functions in an acute stage and delayed functional recovery compared with $B D N F^{+/+}$mice.

\section{Mice with BDNF SNP exhibit reduced proliferating} endothelial cell and vessel density in the peri-infarct area

To assess the effect of BDNF SNP on stroke-induced angiogenesis, the density of proliferating endothelial cells was determined in the entire infarct area at $3 \mathrm{~d}$ after ischemia as an index of angiogenesis. Confocal images of double immunofluorescence showed that nuclear localization of Ki-67, a marker for proliferating cells, is juxtaposed to endothelial CD $31^{+}$cells (Fig. $3 A, B$, arrows). Quantitative analysis showed that the density of proliferating endothelial cells was
A

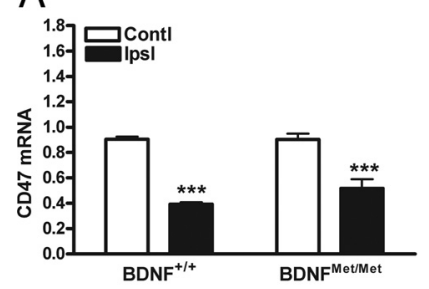

C

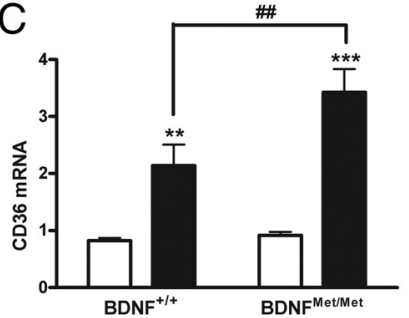

B

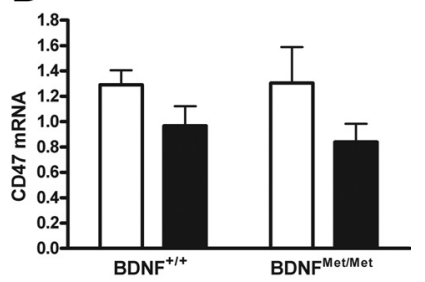

D

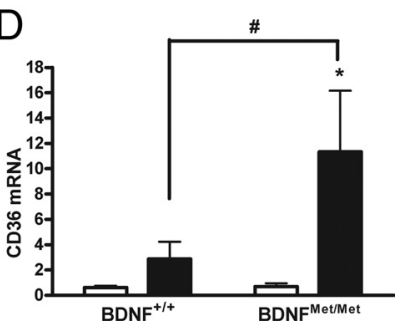

Figure 5. Effect of BDNFVal66Met polymorphism on angiostatic receptor expression. The expression of $C D 47(\boldsymbol{A}, \boldsymbol{B})$ and $C D 36(\boldsymbol{C}, \boldsymbol{D})$ genes were determined in the $B D N F^{+/+}$and $B D N F^{\text {Met/Met }}$ brains at $3 \mathrm{~d}(\boldsymbol{A}, \boldsymbol{C})$ and $7 \mathrm{~d}(\boldsymbol{B}, \boldsymbol{D})$ after stroke. $\beta$-Actin was used for an internal control. $n=6-10$ per group. ${ }^{*} p<0.05,{ }^{* *} p<0.01$, and ${ }^{* * *} p<0.001$ versus contralateral; $" p<0.05$ and ${ }^{\# \#} p<0.01$ versus $B D N F^{+/+}$ipsilateral. Contl, Contralateral; Ipsl, ipsilateral.

significantly reduced in the infarct territory in $B D N F^{\text {Met/Met }}$ mice compared with $B D N F^{+/+}$mice $(p<0.05)$ (Fig. $3 C$ ).

To link the stroke-induced neoangiogenic response to vessel formation, vessel density was determined in the infarct core and inner 
and outer margin of the infarct border $7 \mathrm{~d}$ after ischemia (Fig. 4G). No difference in vessel density was found between genotypes in naive controls (data not shown) or the contralateral side $7 \mathrm{~d}$ after ischemia (supplemental Fig. S3, available at www.jneurosci. org as supplemental material). There was a strong GFAP immunoreactivity in the outer margin of the infarct border representing a glial scar in the ischemic hemisphere (Fig. $4 A, D, G)$. Vessel densities in the outer margin of the infarct were not different between genotypes (Fig. $4 B, E, H$ ). In contrast, the number of vessels in the inner margin of the infarct border were significantly lower in $B D N F^{M e t / M e t}$ mice compared with $B D N F^{+/+}$ mice (Fig. $4 B, E, H$ ), whereas both genotypes showed similarly reduced vessel density in the core (Fig. 4C, F, H). The results show that ischemia induces angiogenesis primarily in the ischemic boundary zone, and BDNF Val66Met SNP influences ischemia-induced vascularization in this area.

Angiostatic factors CD36 and TSP-1 are upregulated in $B D N F^{M e t / M e t}$ mice in response to ischemia

New blood vessel growth is regulated by a well orchestrated balance between proangiogenic and anti-angiogenic factors. To assess the impact of BDNF Val66Met polymorphism on the expression of angiostatic factors, we determined the expression of CD47, CD36, and TSPs. Ischemia reduced CD47 gene expression at 3 and $7 \mathrm{~d}$ to a similar degree between genotypes (Fig. 5A,B).

Unlike CD47, ischemia increased CD36 expression in both genotypes. Additionally, ischemia-induced CD36 mRNA levels in $B D N F^{M e t / M e t}$ mice were significantly elevated at $3 \mathrm{~d}$ compared with $B D N F^{+/+}$mice, and the increase was even more apparent at $7 \mathrm{~d}$ (Fig. 5C,D). The increased CD36 gene expression in the $B D N F^{\text {Met/Met }}$ mice was associated with the increased number of CD36-immunoreactive cells at $7 \mathrm{~d}$ after occlusion (Fig. 6A,B). Subsequent double immunofluorescence revealed that many of the $\mathrm{CD} 6^{+}$cells are endothelial cells in the post-ischemic brain (Fig. 6C-E).

TSP-1 and TSP-2 show high affinity toward CD36, which mediates a signaling cascade that leads to endothelial cell apoptosis (Jiménez et al., 2000). Stroke induced TSP-1 mRNA levels were elevated in both genotypes at $3 \mathrm{~d}$ after ischemia (Fig. 7A). The increase of TSP-1 mRNA levels was sustained in BDNF $F^{\text {Met/Met }}$ mice even at $7 \mathrm{~d}$ after ischemia, whereas the levels returned to baseline in $\mathrm{BDNF}^{+/+}$mice (Fig. $7 B$ ). No significant differences were observed in TSP-2 mRNA levels between genotypes at these times (Fig. 7C,D). The covariance of reduced BDNF levels and increase of TSP-1/CD36 in BDNF ${ }^{M e t / M e t}$ mice shows an unfavorable balance between pro-angiogenic and anti-angiogenic factors that may result in reduced angiogenesis in these mice.

\section{CD36 is critical to reduce stroke-induced angiogenesis in} $B D N F^{\text {Met/Met }}$ mice

To determine whether upregulation of CD36 in BDNF $F^{\text {Met/Met }}$ mice is critical to reduce stroke-induced angiogenesis, we gener-

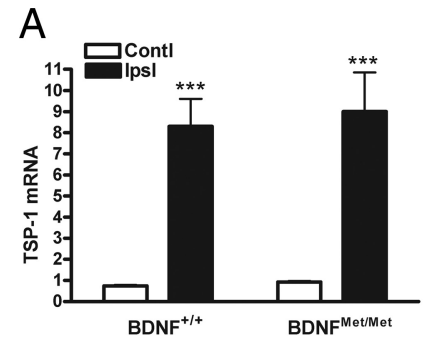

C
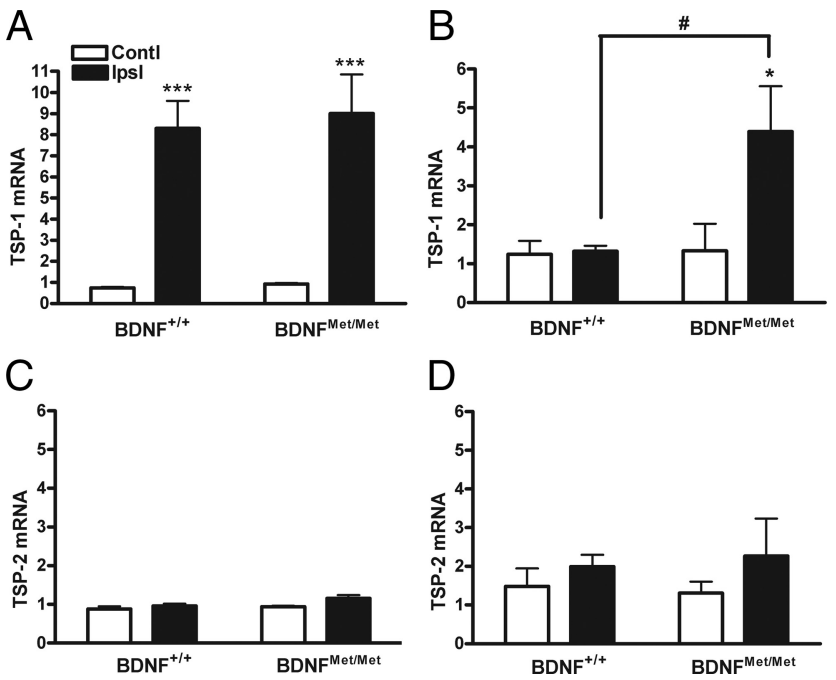

D

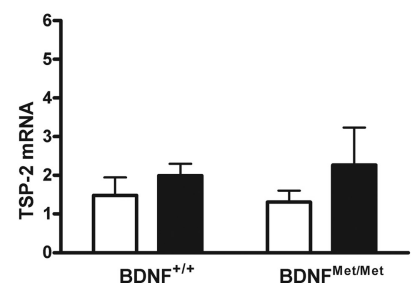

Figure 7. Effect of BDNFVal66Met polymorphism on the expression of TSPs. TSP-1 $(\boldsymbol{A}, \boldsymbol{B})$ and TSP-2 $(\boldsymbol{C}, \boldsymbol{D})$ gene expression was determined in $B D N F^{+/+}$and $B D N F^{\text {Met/Met }}$ mice $3 \mathrm{~d}(\boldsymbol{A}, \boldsymbol{C})$ and $7 \mathrm{~d}(\boldsymbol{B}, \boldsymbol{D})$ after stroke. Note the elevated TSP-1 expression in BDNF ${ }^{\text {Met/Met }}$ mice. $\beta$-Actin was used as an internal control. $n=6$ per group. ${ }^{*} p<0.05$ and ${ }^{* * *} p<0.001$ versus contralateral; ${ }^{\#} p<0.05$ versus $B D N F^{+/+}$ipsilateral. Contl, Contralateral; Ipsl, ipsilateral.

ated $8 \times B D N F^{M e t / M e t} / C D 36 \mathrm{KO}$ double mutant (Dmt) and the corresponding BDNF $F^{\text {Met/Met }} / \mathrm{CD} 36 \mathrm{WT}$ (Dwt) by crossing $B D N F^{\text {Met/Met }}(10 \times$ backcrossed with $\mathrm{C} 57 \mathrm{BL} / 6)$ with $\mathrm{CD} 36 \mathrm{KO}$ (7X backcrossed with C57BL/6). There was a small but signifi- 
A

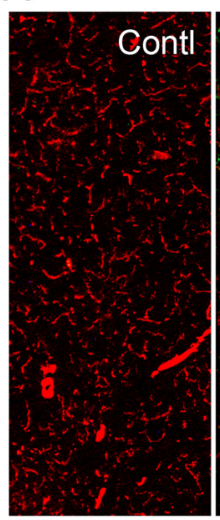

Dwt
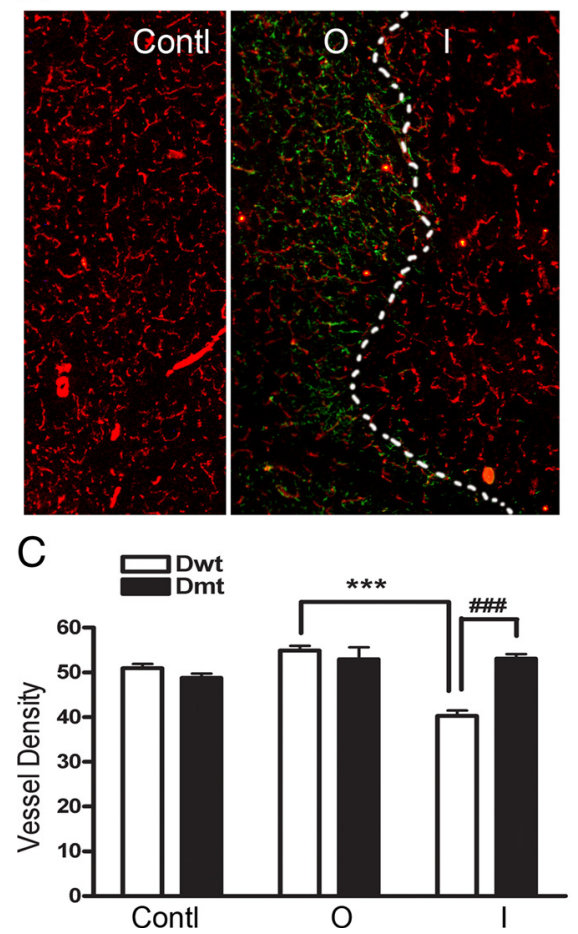

B

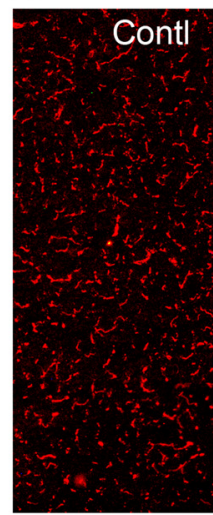

D

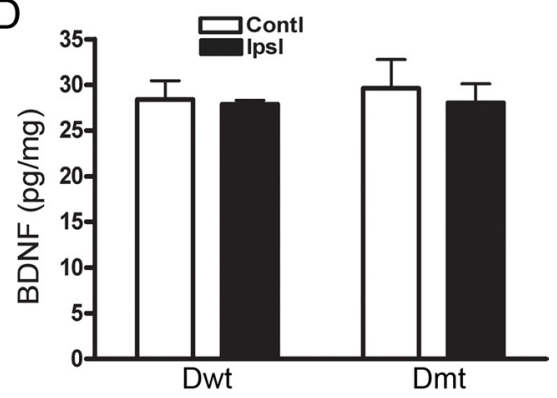

Figure 8. Effect of $C D 36$ on post-ischemic vessel density in $B D N F^{\text {Met/Met }}$ mice. $\boldsymbol{A}, \boldsymbol{B}$, Photomicrographs showed immunohistochemistry of GFAP (green) and CD31 (red) in Dwt and Dmt mice. C, Quantification of vessel density. Vessel density was determined in the outer $(0)$ and inner $(\mathrm{I})$ margin of the infarct border defined by glial scar (dotted lines) and contralateral side (Contl). D, Total BDNF levels from brain lysates in Dwt and Dmt mice were measured by ELISA at $7 \mathrm{~d}$ after ischemia. $n=$ $4-5$ per group. ${ }^{* * *} p<0.001$ versus Dwt outer margin; ${ }^{\# \#} p<0.001$ versus Dwt inner margin. Contl, Contralateral; |psl, ipsilateral side. Scale bar, $300 \mu \mathrm{m}$.

cant increase $(\sim 10 \%)$ in vessel density in the brain of Dwt mice relative to $B D N F^{M e t / M e t}$ mice. This may be attributable to a difference in their genetic background $(8 \times$ vs $10 \times$ backcrossed to C57BL/6) (supplemental Fig. S4, available at www.jneurosci.org as supplemental material). Stroke-induced BDNF levels were not different between Dmt and Dwt mice $7 \mathrm{~d}$ after stroke (Fig. 8D). Dwt mice showed a significant reduction in vessel density in the inner margin of the infarct border but not in the contralateral side or the outer margin of the infarct border (Fig. $8 A, B$ ). Notably, Dmt mice rescued the reduced vessel density observed in this region in the Dwt mice (Fig. $8 A-C$ ), suggesting that CD36 is sufficient to overcome the angiogenic deficit associated with BDNF SNP.

\section{Discussion}

The BDNF Val66Met polymorphism has been linked to human psychiatric diseases. The variant affects the anatomy of the hippocampus and prefrontal cortex, and the carriers of the polymorphism exhibit deficits in hippocampus-dependent memory tasks (Egan et al., 2003; Hariri et al., 2003; Pezawas et al., 2004). Because stroke is a leading cause of disability and $>20 \%$ of Caucasians and up to $70 \%$ of the Asian population carry the BDNF SNP, understanding the impact of the genetic variant of BDNF on stroke pathology may offer significant insights into therapeutics to improve recovery for the patients that have this polymorphism.

A mouse line with the BDNF Val66Met allele knocked in was generated that reproduces the phenotypic traits of humans with the variant (Chen et al., 2006). By using a transient focal ischemia in these mice, the present study showed that BDNF levels were much lower in $B D N F^{M e t / M e t}$ relative to the $B D N F^{+/+}$brain (Fig.
1). Because the tissue used for BDNF protein measurement in the ipsilateral side of the brain included normal non-injured, peri-infarct, and infarct area, the differences in the ischemic infarct territory between the genotypes may be even larger. This finding is interesting in light of previous in vitro studies of the variant BDNF demonstrating defects in activity-dependent BDNF trafficking and secretion (Chen et al., 2004, 2005, 2006). Thus, reduced BDNF levels in the BDNF ${ }^{\mathrm{Met} / \mathrm{Met}}$ brains after ischemia may reflect the defect in activity-dependent secretion and intracellular trafficking at the site of the stroke.

BDNF exists as pro and mature forms that use distinct receptors to mediate divergent neuronal actions. Mature BDNF exerts its biological functions via activation of TrkB, leading to endothelial cell survival/proliferation, whereas proBDNF binds to $\mathrm{p} 75^{\mathrm{NTR}}$ and can initiate apoptosis through sortilin, a co-receptor of p75 ${ }^{\text {NTR }}$ (Nykjaer et al., 2004; Teng et al., 2005). Although our study does not distinguish pro from mature BDNF produced in postischemic brain, the positive link of total BDNF levels to angiogenesis between the genotypes suggests the presence of a sufficient amount of mature BDNF to elicit the biological function in the post-ischemic brains.

The role of BDNF in cerebral ischemia is controversial. Whereas decreased expression of BDNF in haploinsufficient $B D N F^{+/-}$mice is associated with better motor performance and increased neuroblast number after experimental stroke (Nygren et al., 2006), enhanced BDNF availability and/or downstream signaling resulted in reduction or no effect in infarct size but promoted functional recovery (Endres et al., 2000; Kurozumi et al., 2004; Schäbitz et al., 2004, 2007). Our study also shows no discernable differences in infarct size and swelling between the two genotypes. However, the reduced BDNF levels in $B D N F^{\text {Met/Met }}$ mice were associated with greater motor deficits and gait impairment in acute ischemia. In $B D N F^{+/+}$mice, the several deficits exhibited during the acute period $(<7 \mathrm{~d})$ returned to baseline at 2 weeks. However, the deficits in their paw pressure were still present in $B D N F^{\text {Met/Met }}$ mice at that time, indicating delay in functional recovery (Fig. 2). This result is consistent with the report that the presence of BDNF SNP is associated with poor outcome among survivors of hemorrhagic stroke in human study (Siironen et al., 2007). Despite the dissociation of BDNF levels with infarct size, the positive correlation of BDNF levels with locomotor function indicates the presence of underlying BDNFmediated events after stroke.

In response to ischemic insult and subsequent pathological events, regenerative and repair processes occur in affected tissues (Fan and Yang, 2007). Because enhanced angiogenesis in the ischemic penumbra is correlated with longer survival in stroke patients (Krupinski et al., 1994), the impact of BDNF Val66Met polymorphism on angiogenesis in this region was investigated. The findings that $B D N F^{\text {Met/Met }}$ mice have reduced BDNF levels, less proliferating endothelial cells, and reduced vessel density in 
the penumbra relative to $B D N F^{+/+}$mice suggests a causal link between BDNF levels and its functional role in stroke-induced angiogenesis.

The current study shows an involvement of CD36 in the underlying mechanism (s) by which angiogenic deficits in $B D N F^{\text {Met/ }}$ Met occurs. CD36 has exhibited anti-angiogenic effects of TSP-1 in the corneal neovascularization assay, and blocking CD47 has been shown to increase tissue perfusion (Dawson et al., 1997; Isenberg et al., 2007). We found the suppression of the CD47 gene expression in the post-ischemic brain of $B D N F^{M e t / M e t}$ along with wild type, consistent with the report by Jin et al. (2009). The similar degree of reduction in CD47 mRNA levels between $B D N F^{+/+}$and $B D N F^{M e t / M e t}$ mice indicates a minimal involvement of CD47 in regulating BDNF-induced angiogenesis after stroke. In contrast, we showed that ischemia not only induced the expression of CD36 and TSP-1, as reported by others (Hayashi et al., 2003; Lin et al., 2003; Cho et al., 2005), but also that the increase was further potentiated in the $B D N F^{M e t / M e t}$ brain. The relevance of the upregulation of CD36 in stroke pathology is its anti-angiogenic nature, which offsets compensatory angiogenesispromoting cascades in response to tissue ischemia. The reciprocal expression of angiogenic and angiostatic factors found in $B D N F^{+/+}$and $B D N F^{M e t / M e t}$ mice after ischemia thus suggests a possible BDNF-mediated inhibition of the CD36 pathway. The involvement of the CD36 pathway is also supported by the findings that there was a sustained elevation of TSP-1 gene expression in $B D N F^{M e t / M e t}$ mice up to $7 \mathrm{~d}$ after ischemia (Fig. $7 B$ ). Lack of increase in TSP-2 in these mice (Fig. $7 C, D$ ) may be attributable to its delayed expression (Lin et al., 2003). It has been shown that TSP-1 and TSP-2 are also involved in other long-term recovery functions such as synaptogenesis and axonal sprouting (Liauw et al., 2008). These studies showed a distinct temporal and spatial expression of early TSP-1 and delayed TSP-2 expression after stroke. Consistent with the literature, our study also shows a selective increase of TSP-1 and localization of CD36 in the endothelial cell in the $B D N F^{\text {Met/Met }}$ mice 3-7 d after ischemia. Therefore, it is conceivable that early TSP-1 expression may be primarily involved in inhibiting angiogenesis via CD36 during an acute post-stroke but TSP-2 in regulating synaptic plasticity in the long-term recovery through CD36 or other membrane receptors, including integrins, fibronectin, and gabapentin receptor $\alpha 2 \delta$-1 (Adams and Lawler, 2004; Bornstein, 2009; Eroglu et al., 2009).

The sufficiency to inhibit angiogenesis in $B D N F^{\text {Met/Met }}$ mice by elevated CD36 was further addressed. Dmt mice showed a complete rescue in vessel densities of Dwt mice without altering BDNF levels (Fig. 8). The finding that the absence of CD36 does not influence BDNF levels in the post-ischemic brain suggests that the inhibition of CD36 may act downstream of BDNF. Because of an intrinsic phenotype associated with CD36 deficiency, the behavior outcome in Dmt mice was not addressed. Unlike $B D N F^{+/+}$and $B D N F^{M e t / M e t}$ mice that show no discernable difference in infarct volume, CD36 $\mathrm{KO}$ mice exhibit a significantly smaller infarct size, and the neuroprotection resulted in better behavior outcome (Cho et al., 2005). In addition to its role in inhibiting angiogenesis, CD36 mediates free radical production, inflammation, and innate immunity that would influence the development of brain injury and behavior outcome. Thus, angiogenic rescue alone may not reflect behavior outcome in Dmt mice. Despite these caveats, the findings define a clear mechanistic insight by which elevated CD36 expression in BDNF $F^{\text {Met/Met }}$ mice is critical to inhibit stroke-induced angiogenesis.

In summary, using knock-in mouse models of the human genetic variant of the BDNF polymorphism, the present study demonstrates that the BDNF Val66Met polymorphism negatively influences post-stroke motor function, reduces angiogenesis, and elevates angiostatic factors CD36 and TSP-1. Deletion of CD36 in BDNF ${ }^{\text {Met/Met }}$ mice rescues the acute angiogenic deficits. This study links the Val66Met polymorphism to diminished stroke recovery and provides support for the notion that BDNF may influence recovery partly through affecting angiogenesis. It provides a potential stroke therapy that aims at promoting angiogenesis via targeting the CD36 pathway for BDNF Val66Met polymorphism carriers.

\section{References}

Adams JC, Lawler J (2004) The thrombospondins. Int J Biochem Cell Biol 36:961-968.

Bornstein P (2009) Thrombospondins function as regulators of angiogenesis. J Cell Commun Signal 3:189-200.

Chao MV (2003) Neurotrophins and their receptors: a convergence point for many signalling pathways. Nat Rev Neurosci 4:299-309.

Chen ZY, Patel PD, Sant G, Meng CX, Teng KK, Hempstead BL, Lee FS (2004) Variant brain-derived neurotrophic factor (BDNF) (Met66) alters the intracellular trafficking and activity-dependent secretion of wildtype BDNF in neurosecretory cells and cortical neurons. J Neurosci 24:4401-4411.

Chen ZY, Ieraci A, Teng H, Dall H, Meng CX, Herrera DG, Nykjaer A, Hempstead BL, Lee FS (2005) Sortilin controls intracellular sorting of brainderived neurotrophic factor to the regulated secretory pathway. J Neurosci 25:6156-6166.

Chen ZY, Jing D, Bath KG, Ieraci A, Khan T, Siao CJ, Herrera DG, Toth M, Yang C, McEwen BS, Hempstead BL, Lee FS (2006) Genetic variant BDNF (Val66Met) polymorphism alters anxiety-related behavior. Science 314:140-143.

Cho S, Joh TH, Baik HH, Dibinis C, Volpe BT (1997) Melatonin administration protects CA1 hippocampal neurons after transient forebrain ischemia in rats. Brain Res 755:335-338.

Cho S, Park EM, Febbraio M, Anrather J, Park L, Racchumi G, Silverstein RL, Iadecola C (2005) The class B scavenger receptor CD36 mediates free radical production and tissue injury in cerebral ischemia. J Neurosci 25:2504-2512.

Cho S, Szeto HH, Kim E, Kim H, Tolhurst AT, Pinto JT (2007) A novel cell-permeable antioxidant peptide, SS31, attenuates ischemic brain injury by down-regulating CD36. J Biol Chem 282:4634-4642.

Dawson DW, Pearce SF, Zhong R, Silverstein RL, Frazier WA, Bouck NP (1997) CD36 mediates the In vitro inhibitory effects of thrombospondin-1 on endothelial cells. J Cell Biol 138:707-717.

Donovan MJ, Lin MI, Wiegn P, Ringstedt T, Kraemer R, Hahn R, Wang S, Ibañez CF, Rafii S, Hempstead BL (2000) Brain derived neurotrophic factor is an endothelial cell survival factor required for intramyocardial vessel stabilization. Development 127:4531-4540.

Egan MF, Kojima M, Callicott JH, Goldberg TE, Kolachana BS, Bertolino A, Zaitsev E, Gold B, Goldman D, Dean M, Lu B, Weinberger DR (2003) The BDNF val66met polymorphism affects activity-dependent secretion of BDNF and human memory and hippocampal function. Cell 112:257-269.

Endres M, Fan G, Hirt L, Fujii M, Matsushita K, Liu X, Jaenisch R, Moskowitz MA (2000) Ischemic brain damage in mice after selectively modifying BDNF or NT4 gene expression. J Cereb Blood Flow Metab 20:139-144.

Eroglu C, Allen NJ, Susman MW, O'Rourke NA, Park CY, Ozkan E, Chakraborty C, Mulinyawe SB, Annis DS, Huberman AD, Green EM, Lawler J, Dolmetsch R, Garcia KC, Smith SJ, Luo ZD, Rosenthal A, Mosher DF, Barres BA (2009) Gabapentin receptor alpha2delta-1 is a neuronal thrombospondin receptor responsible for excitatory CNS synaptogenesis. Cell 139:380-392.

Fan Y, Yang GY (2007) Therapeutic angiogenesis for brain ischemia: a brief review. J Neuroimmune Pharmacol 2:284-289.

Febbraio M, Abumrad NA, Hajjar DP, Sharma K, Cheng W, Pearce SF, Silverstein RL (1999) A null mutation in murine CD36 reveals an important role in fatty acid and lipoprotein metabolism. J Biol Chem 274:19055-19062.

Febbraio M, Podrez EA, Smith JD, Hajjar DP, Hazen SL, Hoff HF, Sharma K, Silverstein RL (2000) Targeted disruption of the class B scavenger receptor CD36 protects against atherosclerotic lesion development in mice. J Clin Invest 105:1049-1056. 
Febbraio M, Hajjar DP, Silverstein RL (2001) CD36: a class B scavenger receptor involved in angiogenesis, atherosclerosis, inflammation, and lipid metabolism. J Clin Invest 108:785-791.

Gustafsson E, Andsberg G, Darsalia V, Mohapel P, Mandel RJ, Kirik D, Lindvall O, Kokaia Z (2003) Anterograde delivery of brain-derived neurotrophic factor to striatum via nigral transduction of recombinant adenoassociated virus increases neuronal death but promotes neurogenic response following stroke. Eur J Neurosci 17:2667-2678.

Hamers FP, Koopmans GC, Joosten EA (2006) CatWalk-assisted gait analysis in the assessment of spinal cord injury. J Neurotrauma 23:537-548.

Hariri AR, Goldberg TE, Mattay VS, Kolachana BS, Callicott JH, Egan MF, Weinberger DR (2003) Brain-derived neurotrophic factor val66met polymorphism affects human memory-related hippocampal activity and predicts memory performance. J Neurosci 23:6690-6694.

Hayashi T, Noshita N, Sugawara T, Chan PH (2003) Temporal profile of angiogenesis and expression of related genes in the brain after ischemia. J Cereb Blood Flow Metab 23:166-180.

Hayashi T, Deguchi K, Nagotani S, Zhang H, Sehara Y, Tsuchiya A, Abe K (2006) Cerebral ischemia and angiogenesis. Curr Neurovasc Res 3:119-129.

He XM, Zhang ZX, Zhang JW, Zhou YT, Tang MN, Wu CB, Hong Z (2007) Lack of association between the BDNF gene Val66Met polymorphism and Alzheimer disease in a Chinese Han population. Neuropsychobiology 55:151-155.

Isenberg JS, Romeo MJ, Abu-Asab M, Tsokos M, Oldenborg A, Pappan L, Wink DA, Frazier WA, Roberts DD (2007) Increasing survival of ischemic tissue by targeting CD47. Circ Res 100:712-720.

Itoh K, Hashimoto K, Kumakiri C, Shimizu E, Iyo M (2004) Association between brain-derived neurotrophic factor $196 \mathrm{G} / \mathrm{A}$ polymorphism and personality traits in healthy subjects. Am J Med Genet B Neuropsychiatr Genet 124B:61-63.

Jiménez B, Volpert OV, Crawford SE, Febbraio M, Silverstein RL, Bouck N (2000) Signals leading to apoptosis-dependent inhibition of neovascularization by thrombospondin-1. Nat Med 6:41-48.

Jin G, Tsuji K, Xing C, Yang YG, Wang X, Lo EH (2009) CD47 gene knockout protects against transient focal cerebral ischemia in mice. Exp Neurol 217:165-170.

Kermani P, Hempstead B (2007) Brain-derived neurotrophic factor: a newly described mediator of angiogenesis. Trends Cardiovasc Med 17:140-143.

Kermani P, Rafii D, Jin DK, Whitlock P, Schaffer W, Chiang A, Vincent L, Friedrich M, Shido K, Hackett NR, Crystal RG, Rafii S, Hempstead BL (2005) Neurotrophins promote revascularization by local recruitment of TrkB + endothelial cells and systemic mobilization of hematopoietic progenitors. J Clin Invest 115:653-663.

Kim E, Tolhurst AT, Qin LY, Chen XY, Febbraio M, Cho S (2008) CD36/ fatty acid translocase, an inflammatory mediator, is involved in hyperlipidemia-induced exacerbation in ischemic brain injury. J Neurosci 28:4661-4670.

Kokaia Z, Zhao Q, Kokaia M, Elmér E, Metsis M, Smith ML, Siesjö BK, Lindvall O (1995) Regulation of brain-derived neurotrophic factor gene expression after transient middle cerebral artery occlusion with and without brain damage. Exp Neurol 136:73-88.

Kokaia Z, Andsberg G, Yan Q, Lindvall O (1998) Rapid alterations of BDNF protein levels in the rat brain after focal ischemia: evidence for increased synthesis and anterograde axonal transport. Exp Neurol 154:289-301.

Krikov M, Thone-Reineke C, Müller S, Villringer A, Unger T (2008) Candesartan but not ramipril pretreatment improves outcome after stroke and stimulates neurotrophin $\mathrm{BNDF} / \mathrm{TrkB}$ system in rats. J Hypertens 26:544-552.

Krupinski J, Kaluza J, Kumar P, Kumar S, Wang JM (1994) Role of angiogenesis in patients with cerebral ischemic stroke. Stroke 25:1794-1798.

Kurozumi K, Nakamura K, Tamiya T, Kawano Y, Kobune M, Hirai S, Uchida H, Sasaki K, Ito Y, Kato K, Honmou O, Houkin K, Date I, Hamada H (2004) BDNF gene-modified mesenchymal stem cells promote functional recovery and reduce infarct size in the rat middle cerebral artery occlusion model. Mol Ther 9:189-197.

Liauw J, Hoang S, Choi M, Eroglu C, Choi M, Sun GH, Percy M, WildmanTobriner B, Bliss T, Guzman RG, Barres BA, Steinberg GK (2008) Thrombospondins 1 and 2 are necessary for synaptic plasticity and functional recovery after stroke. J Cereb Blood Flow Metab 28:1722-1732.
Lin TN, He YY, Wu G, Khan M, Hsu CY (1993) Effect of brain edema on infarct volume in a focal cerebral ischemia model in rats. Stroke 24:117-121.

Lin TN, Kim GM, Chen JJ, Cheung WM, He YY, Hsu CY (2003) Differential regulation of thrombospondin-1 and thrombospondin-2 after focal cerebral ischemia/reperfusion. Stroke 34:177-186.

Neumann M, Wang Y, Kim S, Hong SM, Jeng L, Bilgen M, Liu J (2009) Assessing gait impairment following experimental traumatic brain injury in mice. J Neurosci Methods 176:34-44.

Nygren J, Kokaia M, Wieloch T (2006) Decreased expression of brainderived neurotrophic factor in $\operatorname{BDNF}(+/-)$ mice is associated with enhanced recovery of motor performance and increased neuroblast number following experimental stroke. J Neurosci Res 84:626-631.

Nykjaer A, Lee R, Teng KK, Jansen P, Madsen P, Nielsen MS, Jacobsen C, Kliemannel M, Schwarz E, Willnow TE, Hempstead BL, Petersen CM (2004) Sortilin is essential for proNGF-induced neuronal cell death. Nature 427:843-848.

Pezawas L, Verchinski BA, Mattay VS, Callicott JH, Kolachana BS, Straub RE, Egan MF, Meyer-Lindenberg A, Weinberger DR (2004) The brainderived neurotrophic factor val66met polymorphism and variation in human cortical morphology. J Neurosci 24:10099-10102.

Rosell-Novel A, Montaner J, Alvarez-Sabín J (2004) Angiogenesis in human cerebral ischemia. Rev Neurol 38:1076-1082.

Schäbitz WR, Berger C, Kollmar R, Seitz M, Tanay E, Kiessling M, Schwab S, Sommer C (2004) Effect of brain-derived neurotrophic factor treatment and forced arm use on functional motor recovery after small cortical ischemia. Stroke 35:992-997.

Schäbitz WR, Steigleder T, Cooper-Kuhn CM, Schwab S, Sommer C, Schneider A, Kuhn HG (2007) Intravenous brain-derived neurotrophic factor enhances poststroke sensorimotor recovery and stimulates neurogenesis. Stroke 38:2165-2172.

Sen S, Nesse RM, Stoltenberg SF, Li S, Gleiberman L, Chakravarti A, Weder AB, Burmeister M (2003) A BDNF coding variant is associated with the NEO personality inventory domain neuroticism, a risk factor for depression. Neuropsychopharmacology 28:397-401.

Siironen J, Juvela S, Kanarek K, Vilkki J, Hernesniemi J, Lappalainen J (2007) The Met allele of the BDNF Val66Met polymorphism predicts poor outcome among survivors of aneurysmal subarachnoid hemorrhage. Stroke 38:2858-2860.

Sklar P, Gabriel SB, McInnis MG, Bennett P, Lim YM, Tsan G, Schaffner S, Kirov G, Jones I, Owen M, Craddock N, DePaulo JR, Lander ES (2002) Family-based association study of 76 candidate genes in bipolar disorder: $\mathrm{BDNF}$ is a potential risk locus. Brain-derived neutrophic factor. Mol Psychiatry 7:579-593.

Slevin M, Kumar P, Gaffney J, Kumar S, Krupinski J (2006) Can angiogenesis be exploited to improve stroke outcome? Mechanisms and therapeutic potential. Clin Sci (Lond) 111:171-183.

Teng HK, Teng KK, Lee R, Wright S, Tevar S, Almeida RD, Kermani P, Torkin R, Chen ZY, Lee FS, Kraemer RT, Nykjaer A, Hempstead BL (2005) ProBDNF induces neuronal apoptosis via activation of a receptor complex of p75NTR and sortilin. J Neurosci 25:5455-5463.

Tongiorgi E (2008) Activity-dependent expression of brain-derived neurotrophic factor in dendrites: facts and open questions. Neurosci Res 61:335-346.

Ventriglia M, Bocchio Chiavetto L, Benussi L, Binetti G, Zanetti O, Riva MA, Gennarelli M (2002) Association between the BDNF 196 A/G polymorphism and sporadic Alzheimer's disease. Mol Psychiatry 7:136-137.

Vilkki J, Lappalainen J, Juvela S, Kanarek K, Hernesniemi JA, Siironen J (2008) Relationship of the met allele of the brain-derived neurotrophic factor Val66Met polymorphism to memory after aneurysmal subarachnoid hemorrhage. Neurosurgery 63:198-203.

Wagner N, Wagner KD, Theres H, Englert C, Schedl A, Scholz H (2005) Coronary vessel development requires activation of the TrkB neurotrophin receptor by the Wilms' tumor transcription factor Wt1. Genes Dev 19:2631-2642.

Wang Y, Bontempi B, Hong SM, Mehta K, Weinstein PR, Abrams GM, Liu J (2008) A comprehensive analysis of gait impairment after experimental stroke and the therapeutic effect of environmental enrichment in rats. J Cereb Blood Flow Metab 28:1936-1950. 